\title{
Unfinished Conversations with Saba Mahmood
}

\section{To Charles Hirschkind in Deep Gratitude}

\author{
Sultan Doughan \\ Boston University \\ sdoughan@bu.edu \\ Jean-Michel Landry \\ Carleton University \\ jean-michel.landry@carleton.ca
}

\begin{abstract}
Saba Mahmood kept open the definitions of her objects of inquiry. She focused on objects such as secularism, piety, and ethics in order to demonstrate what they usher into existence, neutralize, rearrange or disrupt. This mode of inquiry generated a host of questions and opened up new conversations with ongoing trajectories. Influenced by this mode of inquiry, we organized this special issue along the analyses, reflections, and conversations that she opened up, beyond the circle of her interlocutors.
\end{abstract}

\section{Keywords}

Saba Mahmood - anthropological inquiry - methods - secularism - postcolonial critique

If there is a normative political position that underlies this book, it is to urge that we-my readers and myself-embark upon an inquiry in which we do not assume that the political positions we uphold will necessarily be vindicated, or provide the ground for our theoretical analysis, but instead hold open the possibility that we may come to ask of politics 
a whole series of questions that seemed settled when we first embarked upon the inquiry.

SABA MAHMOOD (2005)

Editing a special issue in honor of Saba Mahmood, our late doctoral advisor, has been a demanding journey, both intellectually and emotionally. On the very day of Saba's passing, scholars were exchanging messages of grief and disbelief on social media, some reviving fond memories of meeting her or encountering her work at a certain stage in their trajectory and how it changed them. On the Sociology of Islam email list a conversation ensued over her passing. Those involved in it described Saba as a wellspring for finding fresh perspectives on Islam, feminism, liberalism, and secularism. "Without her brilliance," one contributor wrote, "it would have been impossible [for me] to navigate Jordan on three consecutive years. She rests in power in my books." Over the following weeks, the sense of grief gradually gave way to an awareness. Contributors to the conversation noted how the intellectual tools that Saba crafted over the last two decades were now central to most contemporary discussions on religion, embodiment, and ethics. Yet the grieving did not pass. Seeing a flood of emotion inundating the conversation, sociologist Brian Turner and others suggested that a special issue of the Sociology of Islam journal would be a great way to celebrate Saba's legacy. A few weeks later, Tugrul Keskin, the journal's editor, asked us to edit a special issue in her honor.

In embracing the challenge, we realized that we (as editors) will have to cope with an unavoidable time lag. The issue we had in mind would only come out a year, perhaps two, after Saba's passing. Meanwhile, several memorial events at annual conferences and universities were already in the making. ${ }^{1}$ Special issues and sections dedicated to her work were also scheduled to come out in several other journals. ${ }^{2}$ These events and publications, organized by

1 Memorial events were organized as part of the annual meetings of the American Anthropological Association (November 15, 2018), the Middle Eastern Studies Association (November 17, 2018) and the American Academy of Religion (November 18, 2018). A memorial was held in Berkeley on (April 30, 2018), and in several others universities across the world.

2 See Critical Inquiry 2:1, "Special Section: On the Work of Saba Mahmood" (April 2019); Anthro \{dendum\}, "Saba Mahmood: A Tribute"(April 2018); Comparative Studies in South Asia, Africa, and the Middle East 38:2, "Wrestling with the Violence and Paradoxes of Secular Power: 
Saba's colleagues and companions, have provided venues to revive her memory as a person, interlocutor, and beloved friend. These events also offered the chance to bid farewell to her radiant presence. They were the products of an impressive labor of love. What could another special issue possibly add to these powerful, and often touching, homages?

A special issue on Saba Mahmood should not, in our view, only focus on her person and her work. Anyone interested to know more about her life and scholarly engagements can read her work as well as the remarkable collection of memorial essays and testimonies that have come out across the last years. ${ }^{3}$ Nor did we want to assemble a collection of articles that simply describe or monumentalize her oeuvre. As her former advisees, we had a different perspective. We wanted to pay homage to her by showcasing some of the inquiries, analyses, and reflections that her work made possible.

In the epigraph above, Saba invited her readers to "embark upon an inquiry," as if setting sail upon an ocean with shores yet to be discovered. She used the inclusive "we" ("we-my readers and myself") to invite her audience to join her in this journey. Over the last two decades, this "we" drew an impressive number of readers and scholars who cultivated "a thinking relationship" with Saba-to use the phrase Michael Allen (2018) used to describe the kind of conversations she had with her students in class. These were not placid conversations. Indeed, her classes were often unsettling. ${ }^{4}$ They required one to put a number of inherited assumptions to scrutiny while also acknowledging that many of them could not be entirely abandoned. Cultivating a thinking relationship with Saba meant to suspend our inclination to find correct answers, and instead learn to raise questions that might usefully reframe the object of analysis.

Yet these thinking relationships far exceed the classroom. In assembling this special issue, we had the honor to learn from the work of numerous scholars who are persistently in dialogue with Saba, even if they had never known her in person. While working many of us still hear Saba's voice, inviting us to question our ideas, cautioning us to introduce more nuance. The roundtable conversation included in this volume featuring political scientist Lisa Wedeen and

A Forum on Saba Mahmood's Religious Difference in a Secular Age: A Minority Report" (August 2018). Radical Philosophy 2:05, "Dossier: Saba Mahmood in memoriam" (Fall 2019); Berkeley Center for Religion, Peace \& World Affairs, "Saba Mahmood's Legacy” (July, 2018).

3 See footnote 2 for a selection.

4 On this, see Basit Iqbal, “Saba Mahmood: A Tribute." Anthrodendum (blog). April 19, 2018. 
sociologist Schirin Amir-Moazami brings up the phenomenon of hearing Saba in beautiful ways. In a recently published essay, Webb Keane also notes that Saba is still speaking to him, and that he is still responding to her (Keane 2019).

A reader may ask: how does one enter such a thinking relationship? How does one embark on this journey? Reading and engaging Saba's work is a first step, but there is more. In guiding us into her own mode of anthropological inquiry, Saba often urged us to reflect on what our objects of study (e.g., law, ethics, race or citizenship) enable and disable prior to drawing conclusions on what these objects are. Examining the possibilities that certain concepts and practices unleash or foreclose was, for her, a productive entry point into the anthropological task. Her scholarship illustrated what such an approach can accomplish. In her books, articles and interviews, she kept open the definition of her objects of inquiry (e.g., secularism, blasphemy, ethics). Her focus was rather on what these objects do in the world; what they usher into existence, neutralize, rearrange or disrupt.

Saba's engagement with secularism is a case in point. Given the term's loaded history, she resisted reducing the term to common referents, such as the separation of church and state, or the privatization of faith. For her, these "minimalist" definitions were highly problematic (2015:3), and she spent much of her career writing against them. But throughout the years she devoted to studying secularism, she eschewed the temptation to offer a more accurate, robust or comprehensive definition of secularism. Instead of definitions, she was interested in how secularism transformed the life of religious minorities and pious practitioners.

"My aim," she wrote in one of her first interventions on the topic, "is not to secure an authoritative definition of secularism or to trace its historical transformation within the United States or the Muslim world" (2006: 323). Her refusal was driven by modesty: "My goal is more limited," the text continues. But it could also be read as strategic positioning whereby she kept open the question of what secularism consisted in. Instead of translating a particular case back into a universal concept, she wanted to interrogate how certain concepts (e.g., religious freedom, freedom of speech, minority rights, etc.) shape our understanding of human nature, law, governance, and warfare. By scrutinizing the promise of liberal politics in its effects, Saba took on the task of pointing out how this politics reproduce some of the problem it set out to solve. She did so without advancing or prescribing alternative political ideologies, as Judith Butler (2019) aptly notes.

In subsequent interventions, Saba showed that modern secularism often involves reconfiguring religious life along new lines. The introduction to her last book, Religious Difference in a Secular Age (2015), is probably where she most 
precisely described secularism. She observed that secularism "is not simply the organizing structure for what are regularly taken to be the a priori element of social organization-public, private, political, religious-but a discursive operation of power that generates these very spheres, establishes their boundaries, and suffuses them with content, such that they come to acquire a natural quality for those living within its terms." (2015: 3).

This formulation raises a host of questions: how does secularism establish the boundary between the political and the religious? How does it generate the private, and secure its distinction from the public? How does it naturalize these spheres? But note how theses questions (all "how" questions, those that Saba preferred) shift the problem from one of definitions to one of modality. They bring us into a problem-space driven more by a desire to understand what things make possible (and impossible), than by a will to know what they really are. More by their productivity than their identity.

What we said about Saba's approach to secularism could be said about the other concepts she focused on, such as piety, of which she gave no precise definition. Instead, her book on the Islamic revivalist movement, Politics of Piety (2005), was a profound and sophisticated exploration of what pious practices enabled in specific times and places - in terms of ethics, politics, and subject formation. Similarly, her treatment of terms like "embodiment," "religious freedom," or "hermeneutics" enabled her (and her interlocutors) to raise a number of questions that could not be pursued otherwise.

Saba was certainly not alone in developing this mode of inquiry. Numerous other scholars (anthropologists, historians, philosophers, political theorists) also contributed to it. For Saba and several of her interlocutors, however, tracking the "practical and material unfolding [of concepts] in a society" provided a way to question liberal assumptions about law, the state and the human condition (2015: 23). "My goal," she wrote in the first pages of her first book, "is not just to provide an ethnographic account of the Islamic Revival. It is also to make this material speak back to the normative liberal assumptions about human nature againstwhichsuch amovement is heldaccountable [...]. Myethnographictracings will sustain a running argument with and against key concepts in liberal thought, as these concepts have come to inform various strains of feminist theory through which movements such as the one I am interested in are analyzed" (2005:5).

This mode of inquiry guided our work as editors, from the initial call for contributions to the final choice of articles. We thought that a scholarly public could learn something new about Saba Mahmood by getting a sense of the 
discussions and questions that her work opened up. In our call for papers, we asked how Saba's scholarship influenced other scholars in their intellectual trajectory and in their approach to a variety of themes and concepts that she has examined. The purpose of this issue is therefore to show what Saba's scholarship has made possible for others, and to highlight some of the frameworks and concepts central to her work.

This is not the first publication to attempt such a task. Her intellectual legacy is visible in numerous books, articles, conferences, lectures, seminars, and workshops. ${ }^{5}$ Rather, what we wanted to do was to showcase the work of scholars who were not trained by Saba nor came from the same discipline or tradition of analysis as hers. The scholars featured in this volume raise questions that are different from those that Saba pursued. The value of their contributions lies precisely in this dynamic tension between the demands of their own inquiries and Saba's mode of problematization. The essays collected here do not monumentalize Saba Mahmood's work, but rather, push it in new and often unforeseen directions.

If commemorations and celebrations bring to life by infusing spirit to desired form, this issue lives through and in the on-going conversations with Saba Mahmood. If, as Judith Butler wrote, Saba "wanted to live on in the angry response and clear analysis to the annihilating force of present powers, in the desire to imagine and live in a world without shying away from its brutality or its wonder" (Butler 2019, pp.8-9), this issue brings together a range of responses and analyses in which Saba's thought lives on. In the desire to imagine, live and understand the world after Saba Mahmood, we have embraced the condition of unfinished conversations and the possibility that our thinking relationship with her will not be finished even when the page turns blank.

The six research articles and the roundtable discussion included in this volume variously engage Saba Mahmood's work beyond the discipline of anthropology. We open with an ethnographic analysis by anthropologist Kristen Wesselhoeft examining how French women racialized as Muslim rethink key

5 Several generations of students have already pursued her legacy in productive ways; among them are Michael Allan, Kabir Tambar, Noah Salomon, Katherine Lemons, Mayanthi Fernando, Angie Heo, Lucinda Ramberg, Nazaneen Shahroknin, Yasmeen Daifallah, Patricia Kubala, Ian Steele, Bruno Reinhardt, Nadia Fadil, Sarah Bracke, Mareike Winchell, Aaron Eldridge, Milad Odabaei, Basit Iqbal, Candace Lukasik, Brent Eng, and us: Sultan Doughan and Jean-Michel Landry. 
liberal concepts—such as choice, freedom and rights—as part of their effort to lead pious lives. Wesselhoeft astutely notes that both public discourse and social scientific scholarship tend to frame secular liberalism and Muslim piety as divergent (if not incompatible) projects. In order to challenge this opposition, she draws on Mahmood's insight that secularism does not only fashion the subjectivities of those embracing it, but also transforms those who resist its power.

Wesselhoeft's ethnographic account is critical: she insists that if her interlocutors are not hostile to the liberal injunction to assert one's autonomy, the moral language of choice nonetheless orients and constrains their religious life. Her interlocutors are "constrained to choose." To illuminate how the language of choice become, for French women, an inescapable part of their attempts to develop pious dispositions, Wesselhoeft turns her attention to the ideal of sisterhood [soeurénité]. She explores how pious Muslims use sisterhood to reconfigure the practice of gender separation [non-mixité] as an ethical project in a context where gender mixing remains the norm.

Historian Karl Shuve's article also explores practices constitutive of gender and piety, but in a very different historical context - that of twelfth-century monastic life of the Holy Roman Empire. Focusing on the epistolary correspondence of two female monastic leaders, namely Hildegard of Bingen and Tengswich of Andernach, Shuve shows how Mahmood's insights can help historians reframe their analysis of Christianity - and in this case of medieval practices that presuppose the acceptance of the structures of masculine domination.

At the heart of the monastic correspondence analyzed by Shuve is the practice of nuns taking the veil during consecration, marking them as "brides of Christ." While Mahmood ethnographically studied veiling practices among pious Cairene Muslims, Shuve argues that the questions she raised about agency and ethical formation open up new analytical possibilities in the study of Christianity and feminist historiography as well. Inspired by Mahmood's invitation to move beyond the subordination and resistance binary, Shuve shows that "far from being a static symbol of masculinist oppression, [the medieval practice of veiling] was a contested and variable practice that gave rise to competing subjectivities."

Sociologist Brian Turner revisits Mahmood's Politics of Piety, and shows that the theory of practice it contains provides an alternative to Pierre Bourdieu's secular approach to human agency. He observes that Bourdieu's understanding of religious traditions and pious practices remains profoundly Durkheimian: religion is treated as symptomatic of a "deeper structural reality" whose force is always entirely social and determined by socioeconomic constraints. 
As such, Bourdieu's "habitus seems to rule out any agency" thereby missing a key component: human flourishing (eudemonia).

Turner contends that Mahmood's analysis of Islamic piety movements provides a more adequate theory of practice. He highlights Aristotle's influence on Mahmood's understanding of key concepts like ethics, embodiment, and habitus-a point he sees missing in the secondary literature on Politics of Piety. For Aristotle, writes Turner, "eudemonia [human flourishing] cannot only be achieved outside a flourishing polity." Hence, Mahmood was able to analyze the ethical dimension of human action without losing sight of its political implications. Her concept of agency offered a compelling framework to understand pious action, while also highlighting the secular assumptions that underlie sociological research on religion.

Historian Timothy Gutmann turns to Mahmood's work to understand the forms of inclusion/exclusion that operate in mixed and un-mixed spaces. He focuses on debates provoked by the introduction of modern educational standards in 19th century Ottoman Beirut which introduced mixed-confession schooling - a principle supported by the reformist thinker Muhammad 'Abduh, while perceived as a threat to the distinctiveness of the Muslim community by the scholar and mystic poet Yūsuf al-Nabhānī.

Gutmann's careful analysis of these debates challenges the liberal belief that education naturally promotes tolerance and inclusiveness. Drawing on the writings of modern figures such as 'Abduh, and al-Nabhānī, as well as on those of al-Ghazāli and Ibn Taymiyya, he shows that instead of eliminating suspicions of difference, modern education "reconstitutes them in the new spaces it creates." His reading of premodern thinkers allows him to reconstruct the ethics of intimacy that long oriented the practice of Islamic education, and informed al-Nabhānī's sensibility. He concludes that the "fear of a loss of a community's distinctiveness, and conversely of a concealed other in its midst, is constitutive of the modern imaginaries of shared space."

In "Secular Governance and Islamic Law: The Globalization of the Minority Question" sociologist Alexandre Caeiro pushes Mahmood's problematization of the minority question in new directions by considering how the concept of minority helps us rethink previously established religious inequalities. While acknowledging that the notion of minority belongs to a strategy of secular governance, Caeiro also describes it as "a tool used by a set of actors in pursuing different projects." Caeiro attends to several interlocking issues by focusing on the internal debates within Islamic jurisprudence $[$ iqh $]$ on Muslims in the West and non-Muslims in the world of Islam as they were taken up by Islamic scholars and public intellectuals. First, he describes how "this discourse bears traces of $[. .$.$] secular ambition." Then, he goes on to argue that Islamic traditions$ 
often seen as foundational in shaping religious inequalities and "the life of non-Muslims in the Middle East are in fact more ambiguous in their effects than may appear at first sight."

Caeiro approaches secular governance as a global structure shaping these debates, and prompting these Islamic scholars and intellectuals to engage the demands of liberal citizenship by resignifying the Arabic word aqalliya to capture the concept minority. His article brings together these transnational debates in the Islamic minority discourse [figh al-aqalliyat] while carefully showing that the minority concept, as a tool, is doing a double work with wide reaching consequences. For these scholars, minimizing or emphasizing difference in order to demand rights for religious minorities within Europe or the Middle East, however conceptually varied, bear the danger to undermine agency and/or the political issues at hand.

In the final article, political philosopher Christoph Baumgartner seeks to redeem certain aspects of secularism as a viable form of life by writing from a self-reflexive liberal point of view. Working with the notion of "ethical thematization of religious difference," he attempts to rethink secularism from within and to go beyond a legalistic approach. By building on the philosopher Rahel Jaeggi's definition of "form of life" he reworks secularism as a tool of problemsolving in social settings. He makes a case for other possibilities of liberal inclusion of religious differences and practices in public life beyond the formal regulations of religious difference.

Baumgartner's argument hinges on his analysis of Muslims' refusal to shake hands with members of the opposite sex and how this practice can be accommodated by the non-Muslim majority in various European contexts. More specifically, he asks how Muslims navigate and how non-Muslims accept, accommodate and/or co-thematize this phenomenon, in order to solve the issue. Thus, he makes a case for how secularism can resolve problems arising out of religious dispositions through what Saba Mahmood calls "ethical thematization".

The volume concludes with a roundtable conversation convened by Sultan Doughan and Candace Lukasik between political scientist Lisa Wedeen and sociologist Schirin Amir-Moazami. The conversation focuses on Mahmood's impact on the discussants' respective fields with regards to the study of Islam and the Middle East. Both accounts highlight the range of possibilities she made thinkable beyond the binary framework of resistance vs. domination. Moreover, both scholars mention how Mahmood's work helped them situate questions of ethics in the domain of politics. Her early work in particular pushed them to reflect their own thinking more productively in relation to secularism and state-citizen relations. 
On the influence of Mahmood's work, both Wedeen and Amir-Moazami insist that it remains highly influential in comparative politics, gender theory and Islamic studies. Wedeen points out that one could place Mahmood's work in conversation with a range of canonical literature in political science such as Marx's On the Jewish Question or Hegel's Phenomenology of Spirit as well as with contemporary liberal political theory in order to rethink those texts in light of the critiques she formulated. For her, reading these earlier works side-by-side with Mahmood's would be an exercise in rescuing political theory from its Eurocentrism. By contrast, Amir-Moazami offers a different view from the perspective of German academia, where secularist voices are celebrated as the ultimate form of reason. She notes that students find Mahmood's work hard to grasp, given her sharp critiques of liberalism and secularism, and the fact that she does not offer an alternative normative project and solution. She contends that more work needs to be done in order translate Mahmood's work conceptually and make it relevant for contexts beyond the Middle East and the United States. This last point is one that both Wedeen and Amir-Moazami agree on. They point out that Mahmood's work remains relevant, but yet to be fully disclosed, yet to be translated and to be engaged with for further critical discussion that points ways out of our self-perpetuating Eurocentrism.

\section{Acknowledgements}

This special issue would not have been possible without the sharp intellect, kind support and generous help of friends and colleagues, such as Manan Ahmad, Michael Allan, Benjamin Berger, Jon Bialecki, James Bielo, Brandon Bloch, Charles Butterworth, Yasmeen Daifallah, Yazan Doughan, Nadia Fadil, Samer Ghamroun, Katherine Göktepe, Katherine Lemons, Candace Lukasik, Nada Moumtaz, Elayne Oliphant, Bruno Reinhardt, Kabir Tambar, and Hannah Tzuberi. Their inputs and opinions have been invaluable. We also want to thank Charles Hirschkind for providing continous support and advice during all stages of this project. His professional and caring guidance has been a reassuring force whenever we faced a new challenge. Whatever deficiencies remain or mistakes were made in this special issue, they are entirely ours (Sultan \& Jean-Michel).

\section{References}

Allan, Michael (2018). Reading with Saba. Saba Mahmood Legacy. Georgetown University. June 6, 2018. 
Butler, Judith (2019). Thinking with Saba Mahmood. Critical Times 2 (1): 5-9.

Iqbal, Basit. (2018). Saba Mahmood: A Tribute. Anthrodendum. April 19, 2018.

Keane, Webb (2019). Saba Mahmood and the Paradoxes of Self-Parochialization. Critical Times 2 (1): 3-4.

Mahmood, Saba (2005). Politics of Piety. The Islamic Revival and the Feminist Subject. Princeton, NJ: Princeton University Press.

Mahmood, Saba (2015). Religious Difference in a Secular Age: A Minority Report. Princeton, NJ: Princeton University Press.

Mahmood, Saba (2006). Secularism, Hermeneutics, and Empire: The Politics of Islamic Reformation, Public Culture 18 (2): 323-347. 